\title{
Performance of EcoSan Toilets at Majumbasita in Dar Es Salaam - Tanzania
}

\author{
AS Mahenge \\ Environmental Engineering Department, Ardhi University, P. O. Box 35176, Dar-Es-Salaam, Tanzania \\ anesimahenge@gmail.com
}

\begin{abstract}
The performance of Ecological Sanitation (ECOSAN) toilets at Majumbasita-Ukonga in Dar es Salaam, Tanzania was studied in order to assess their feasibility for low cost and effective environmental protection. The studied parameters for urine were $\mathrm{pH}$, $T K N$, phosphorus, potassium and E-coli and for faecal sludge were temperature, $p H, T S, V S, C O D, T K N$, ammonium, phosphorus, potassium and Ascaris eggs. Results indicated a high $\mathrm{pH}$ up to 10.3 in the faecal contents due to addition of ashes. The temperatures were between $27^{\circ} \mathrm{C}-31.7^{\circ} \mathrm{C}$ during the whole study period. The total COD measurements varied from $33-74$ gCOD/l, while TS and VS were respectively 57-81 gTS/l and 21 - $46 \mathrm{gVS} / \mathrm{l}$. The results for TKN, ammonium, phosphorus and potassium in faecal sludge were $5045-$ 6080mg/L, 5207-5852 mg/L, 29-70mg/L and 105-176 $\mathrm{mg} / \mathrm{L}$, respectively. Ascaris eggs were efficiently removed from faecal sludge that were strictly dry and had a $\mathrm{pH}$ of more than 10. The results for TKN, ammonium, phosphorus and potassium in urine were 4285-5010 $\mathrm{mg} / \mathrm{L}, 111-195 \mathrm{mg} / \mathrm{L}$ and 190-251 $\mathrm{mg} / \mathrm{L}$, respectively. $E$ Coli were present in urine with $p H$ less than 11.5 and were efficiently removed from urine with $\mathrm{pH}$ more than 11.5. Presence of pathogens in urine implies the separated urine can be reused in tree growing and not for fertilising food crops consumed raw.
\end{abstract}

Keywords- ECOSAN toilets, Faecal Sludge, Urine, Performance, Environmental protection.

\section{INTRODUCTION}

Environmental sanitation problems have continued to grow in complexity despite receiving little attention in Tanzania. The hygienic disposal of excreta that does not endanger health and welfare of the community is important (Obeng et al, 2015; Hu et al, 2016)). There are many constraints in improving the existing sanitation situation that centre on political, economic, social and cultural contexts of health and disease. Serious constraints (Obeng et al, 2015), which are still prevalent to-date, are: funding limitations; insufficiency of trained personnel; operation and maintenance; logistics; inadequate costrecovery framework; insufficient health education efforts; inappropriate institutional framework; intermittent water service and non-involvement of communities. Given the inherent unsustainability of large scale sewerage, on-site sanitation concepts, dealing with human excreta collection and treatment on-site, that is, the location where it is deposited, can provide a hygienic and satisfactory solution (Obeng et al, 2015; Taseli, 2016; Mahenge, 2013; Shen, 2013), because it is not an expensive and high technology. For reuse of human "waste" and turning it into something "useful and valuable" (Breslin, 2014; Esrey, 2001), ecological sanitation (ECOSAN) had been introduced as a pilot scale at Majumbasita-Ukonga in Dar-es-Salaam city, Tanzania by EEPCO (Environmental Engineering and Pollution Control Organization - Non Governmental Organisation) through UNICEF funding. These introduced toilet systems are in the category of improved pit-toilets and they are 'dry' accumulation systems or so-called ECOSAN toilets which receive only faeces. Moreover, after faeces deposit, ashes are added to increase the $\mathrm{pH}$ and reduce moisture. If the moisture content and ashes additions are balanced, it is believed that the faeces will decompose to form a soil conditioner in about four months (Esrey et al, 2001). This idea of decomposition was given without thorough exploration of the conditions needed for biodegradation to proceed and was further ascertained in this study. Pathogens are killed in the dry alkaline compost that can be used as soil fertilizer. The urine is collected separately and can also be used as fertilizer (Esrey et al, 2001). To get an insight in the performance of these structures the following study objectives were to: Get the baseline information related to composting toilet systems in the country; Check the performance of composting toilets in pre-treatment of human excreta; Verify the quality of separated human urine, as it is believed to be sterile, people are using it directly in agriculture without knowing the safety associated with its re-use.

\section{MATERIALS AND METHODS}

\subsection{Description of the Research Area}

Majumbasita, is one of the unplanned settlements at the peri-urban part of Dar-es-Salaam city in Tanzania. It is about $11 \mathrm{~km}$ from the city centre, in the western direction and closer to the Dar-es-Salaam International Airport (DIA) in Kipawa ward, Ilala Municipality; with a 
population of about 23,000 inhabitants. Houses are mostly occupied by owners, with few inhabited by tenants. The size of plots varied from about $170-400$ square metres (EEPCO, 2007) during study. The piped water supply from the city network is inadequate for the inhabitants; $85 \%$ depend on well water (Mato, 2002) and are forced to use hand-dug wells although the quality is doubtful (Elisante and Muzuka, 2017; Addo, 2016). It was noted that there is intermittent supply of water per week; that is, the supply was for 2-4 hours per supply (Elisante and Muzuka, 2017). Only 5\% of the residents get it once per week, $63.2 \%$ two days/week, $28 \%$ three days/week, $2 \%$ four days/week and $1.2 \%$ manage to get water for $>4$ days/week. Moreover, their laboratory results revealed that, E-Coli count for samples from boreholes with depths 1.8 metres and 6.75 metres were $3000 \mathrm{FC} / 100 \mathrm{ml}$. and $178 \mathrm{FC} / 100 \mathrm{ml}$, respectively (Mato, 2002; Addo, 2016). The intensity of E-Coli showed a decreasing trend with depth. The wells deeper than 70 metres due to increase in pressure were free from faecal contamination implying that, water from deeper soil layers was bacteriologically safe for drinking purposes at that moment. Similarly, for the piped water supply in that area, it was observed that, there was an increase in faecal pollution in the service pipes (values ranged from $3-76$ FC/100 mL for 25 sampling points chosen). The area experiences high water table (HWT) evidenced by the raised pit toilets $(75 \%)$ in the area, while some dwellers $(4.8 \%)$ did not have any toilet facility; they use neighbours toilets (EEPCO, 2007, Elisante, Mato, 2002 and Muzuka, 2017).

\subsection{Schematic Presentation and Functioning of ECOSAN Toilets}

The schematic presentation of ECOSAN toilet at Majumbasita is as shown in Figure 1.

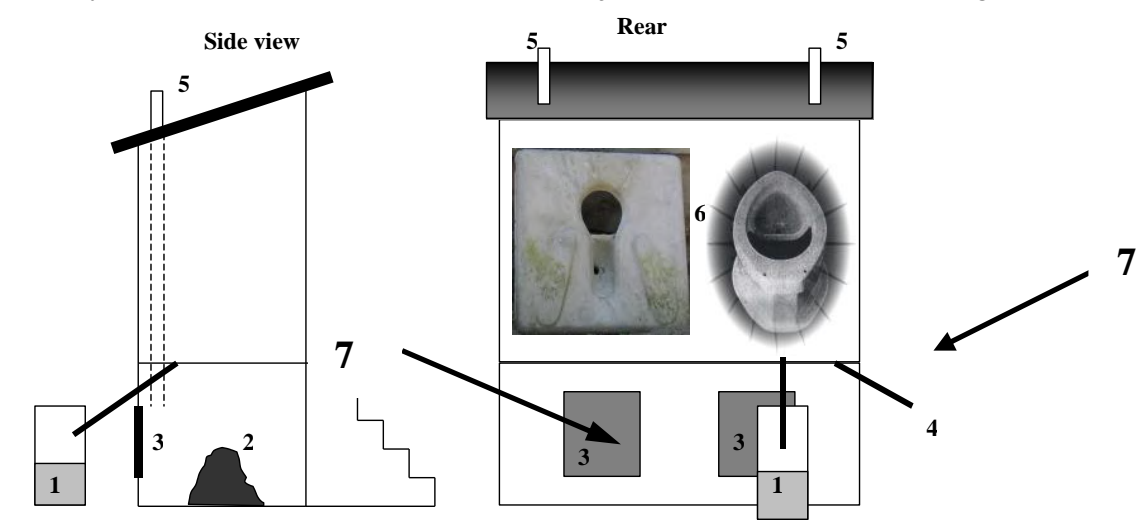

Fig.1: Photographs of caption of the ECOSAN toilet at Majumbasita

Symbol's Explanation:

(1) Urine tank of 20 litres capacity (2) Accumulating faeces and ashes heap in the toilet vault (3) Doors at the back of the pit-chamber for desludging purposes(4) Wash water outlet (5) Vent pipe (6) Drop hole slabs (squatting and seating type) (7) Separated Urine hole.

The components of the ECOSAN include two pits, two openings for removal of dehydrated faecal material, two vent pipes (for each pit), two squatting pans or one squatting pan and one seat riser, or two seat risers, two urine drain pipes and one drain pipe for anal cleansing water, one plastic container for urine, superstructure, squatting slab and roof. The components are provided in duplicate because when one component is in use, the other one is on stand-by basis. If the pit in use is full, it is closed for a time and the other stand-by pit is opened for use. It is expected that, the dehydrated material in the closed pit decomposes for a period of not less than 6 months and then the system will be desludged and the sludge used in agriculture. So far none of the systems has been desludged. Normally, after defecation, a handful of ashes from charcoal stoves or burnt wood ashes are poured into the pit. Ashes (charcoal/plant ash) are added inside the faecal chamber to raise $\mathrm{pH}$ (for pathogen destruction), reduce odour and dehydrate the faecal material. The $\mathrm{pH}$ must be $\geq 10$ because it is unfavourable $\mathrm{pH}$ for most pathogens especially ascaris (Taseli, 2016). Obeng remarked that, estimating the volume of ash is difficult (Obeng et al, 2015). Experiences indicates that approximately twice the volume of faeces has to be added (Vliet et al, 2013) while, Kujawa suggested five times the volume of faeces or $0.3 \mathrm{~m}^{3}$ per person per year for all waste (Kujawa-Roelveld, 2016). At Majumbasita 0.1-0.33 litre of ashes/person/day/defecation is added without formal control of the amount. The charcoal ashes are kept inside the superstructure on the squatting slab in order to avoid inconveniences. No water or any liquid material is allowed to mix with faeces inside the chamber. However, due to the religious beliefs of some people, water must be used for anal cleansing and hence, a place in between the two squatting holes was modified to cater for cleaning purposes and the wash-water led to the outside through a pipe. For this purpose, a small plastic water container of 5 litres is provided for this need. The wash water is not treated but ends up in the surrounding area signifying a 
need for proper disposal. The 20-litre urine tank is kept outside and usually emptied when it is full.

\subsection{Sampling and Analysis}

Samples were collected from 10 ECOSAN toilets. A sampling device with specifications: Model - Eijcamp; Made is Agrisearch Equipment, was used to collect faeces. One kilogram of faecal sludge and one litre of urine were collected per toilet for laboratory analysis. Analyzed parameters in faeces were $\mathrm{pH}$, ambient temperature of the samples, COD, TS, VS, TKN, $\mathrm{NH}_{4}{ }_{-}-\mathrm{N}$, $\mathrm{PO}_{4}^{-3}-\mathrm{P}, \mathrm{K}$ and Ascaris eggs. Analyzed parameters in urine were $\mathrm{pH}, \mathrm{TKN}, \mathrm{PO}_{4}^{-3}-\mathrm{P}, \mathrm{K}$ and $E$-coli. The parameters were determined by using Standard Methods (2002).

\section{RESULTS AND DISCUSSION}

\section{1 pH, Temperature and Ascaris Eggs Results in} Faecal sludge

The $\mathrm{pH}$ ranged from $8.3-10.3$ due to addition of ashes. The correlation by SPSS between $\mathrm{pH}$ and age of sludge is highly significant at $\mathrm{P}<0.001$.It was furthermore evident that, the $\mathrm{pH}$ increases with increasing age of sludge in the toilet vault. Similarly, the ANOVA showed the same conclusions with $\mathrm{R}^{2}$ of $63 \%$. Tropical condition temperatures observed, $27-29.9^{\circ} \mathrm{C}$ coupled with the $\mathrm{pH}$ suggests that, it is possible to have mesophilic digestion in the bottom part of the heap of feaces in ECOSAN pit only during the first months of operation. After that the $\mathrm{pH}$ goes up and it is logical to assume that no digestion goes on. The results in Ascaris eggs varied from $0-4000$ counts/1000 mg. Ascaris eggs were efficiently removed from faecal sludge that were strictly dry and had a $\mathrm{pH}$ of more than 10 .

\subsection{COD, TS and VS Results in the Faecal Sludge for ECOSAN Toilets}

The results in Table 1 indicate a TS range of 57 to 81 gTS/l, which is low range considering that the TS-content of fresh faeces is about $254.62( \pm 4.19) \mathrm{gTS} / \mathrm{kg}$ (Strande and Brdjanovic, 2014). Given the nature of toilet use, that is, with addition of ashes, it was anticipated to find higher TS values, and therefore, apparently, the urine was not completely separated. Even a small amount of urine going cumulatively into the faeces vault can lead to relatively low TS values. The total COD concentration in faecal material ranged from 33 to $74 \mathrm{~g} C O D / 1$ whereas the values for VS were between 21 - $46 \mathrm{gVS} / 1$. The VS and COD concentration decreased with time due to the addition of the ashes (dilution). Table 1 results are within the literature reported values for faecal sludge from toilets and unsewered public toilets quality in different cities noted by Water Resources Research Institute (WRRI) in Accra, Ghana and SANDEC (Water and Sanitation in Developing Countries). They conducted numerous analyses of untreated septage and public toilet sludges and results reported by Semiyaga (2015), which varied from 49-97 gCOD/l. This also confirms that, the ECOSAN faeces accumulation chamber suffered from an intrusion of urine. The calculated average of COD:VS ratio was $1.57 \mathrm{gCOD} / \mathrm{gVS}$, but it varied between 0.67 $2.47 \mathrm{gCOD} / \mathrm{gVS}$. Such a condition might be due to the fact that varying amount of ashes are added after defacation and therefore making the sludge in the vault to be inhomogeneous.

Table.1: The experimental results of human faecal sludge for ECOSAN toilets at Majumbasita

\begin{tabular}{|l|c|c|c|}
\hline Age of Toilet (months) & $\mathbf{4}$ months average & 6 months javerage & 8 months average \\
\hline pH & 8.3 & 9 & 10.3 \\
\hline Total COD (g/l) & 74 & 52 & 33 \\
\hline TS (g/l) & 57 & 71 & 81 \\
\hline VS (g/l) & 46 & 34 & 21 \\
\hline VS/TS (\%) & 81 & 47 & 25 \\
\hline COD/VS & 1.61 & 1.53 & 1.57 \\
\hline NH4 ${ }^{+}$-N(mg/l) & 5852 & 5207 & 5418 \\
\hline Total-N(mg/l) & 6080 & 6077 & 5045 \\
\hline PO4 ${ }^{3--P(m g / l) ~}$ & 60 & 70 & 29 \\
\hline K(mg/l) & 105 & 176 & 141 \\
\hline Ascaris eggs $(/ \mathbf{1 0 0 0}$ mg) & 667 & 273 & 0 \\
\hline
\end{tabular}

3.3

Kjedahl Nitrogen, Total Nitrogen, Phosphorus and ammonium in faecal sludge
The ammonia-nitrogen concentrations for faecal sludge from undiluted samples from ECOSAN toilets ranged between 5207 - $5852 \mathrm{mg} \mathrm{NH} 4-\mathrm{N} / \mathrm{L}$ on the day of 
sampling, while the TKN values varied from 5045-6080 $\mathrm{mg} / \mathrm{L}$, values that are similar to those obtained by Strauss and Heinss (1995). Their result ranged between $2800-$ $6000 \mathrm{mg} / \mathrm{l}$. The phosphorus and potassium results found varied from $29-70 \mathrm{mg} / \mathrm{L}$ and $105-176 \mathrm{mg} / \mathrm{L}$, respectively. These results are comparable with those found by Mashauri and Senzia (2002) for ECOSAN toilets at Majumbasita which were $28.5 \mathrm{mg} / \mathrm{L}$ and 166.43 $\mathrm{mg} / \mathrm{L}$ for phosphorus and potassium, respectively.

\subsection{Urine}

The assessed $\mathrm{pH}$ of the collected urine from ten (10) ECOSAN toilets ranged between 6.27-11.80 and the temperature from $26.1-31.7{ }^{\circ} \mathrm{C}$. From the fact that, the urine $\mathrm{pH}$ was 6-7 when excreted, but during its storage would raise to between 9-9.4 as a result of the degradation of urea (Hijikata et al, 2015), the higher values found in our measurements implies that, there is a certain amount of ashes which went into the urine tank. Furthermore, the results show that all of the toilets with $\mathrm{pH}$ less than 11.5 in urine were found with $E$-coli at a range of $50-4500$ counts. The detection of E-Coli counts in the urine storage tanks indicates there were faecal contamination and escape of ammonia gas from urine tanks (i.e the tanks were not airtight). With adequate separation, the "pure" urine is expected to be free of pathogens (Mahenge, 2013) but about $50 \%$ of the toilets were out of the maximum WHO Guidelines for unrestricted reuse in agriculture (1000 counts $/ 100 \mathrm{ml})$ especially for crops eaten raw; this could be risky. The result suggests that, direct use of urine separated in Majumbasita into the gardens could introduce pathogens into the soil and may infect vegetables, which then obviously represents a health hazard. The $\mathrm{pH}$ results compares with those found by Farzadkia (2014) for double vault-urine diverting (DVUD) toilet which where from 6.2-13.0 due to addition of additives. Nakagiri and Niwagaba (2016) found out that, addition of lime, ash and soil resulted in corresponding $\mathrm{pH}$ values of $11,9.4$ and 8.8. However, they found that, $\mathrm{pH}$ of $11-12$ is reached in treatment methods using lime. The $\mathrm{PO}_{4}-\mathrm{P}$ results in the urine were 111-195 mg $\mathrm{PO}_{4}-\mathrm{P} / \mathrm{L}$ and they are comparable to KujawaRoelveld, (2016). The TKN and potassium values were 4285 - $5010 \mathrm{mg}-\mathrm{N} / \mathrm{L}$ and 190-251 $\mathrm{mg} \mathrm{K} / \mathrm{L}$, respectively.

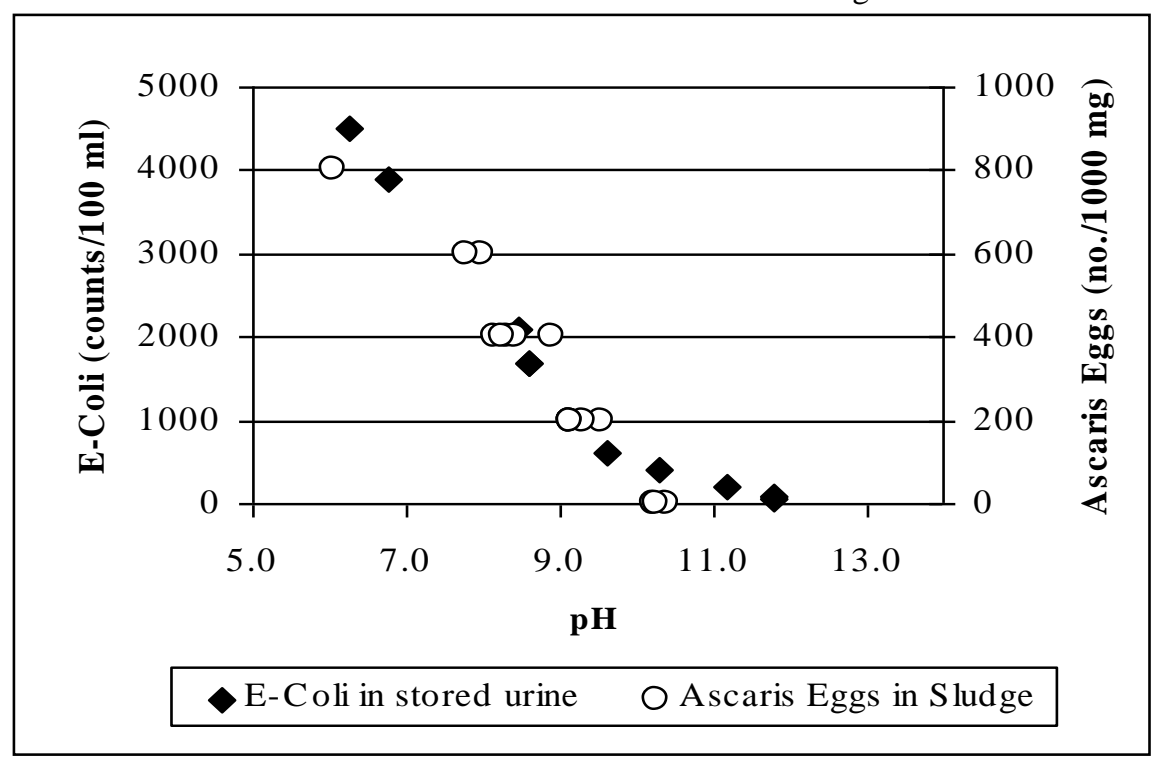

Fig.2: The E-Coli, Ascaris eggs and pH results in sludge and urine of ECOSAN toilets

\section{CONCLUSIONS}

By using the ECOSAN toilets, such as those installed in Majumbasita, groundwater contamination can be avoided, since they are constructed above ground. More information needs to be collected as to the amount of ash(es) to be added to the toilet vault, the proposed 3 times the volume of faeces will occupy the main part of the volume of the chamber. A complete separation of pure urine seems to be difficult for users as evidenced by faecal coliforms observed in urine. The separated urine can be used directly as fertiliser in tree growing, but not for fertilising food crops that are consumed raw, due to presence of pathogens. The extent of biological sludge stabilization is likely to be small in view of the prevailing high $\mathrm{pH}$ values. A lot of urban small scale agriculture needs to be developed in order to enable the reuse of all the collected sludge and urine, otherwise, transport for reuse outside the city is necessary. Ascaris eggs and EColi are efficiently removed in ECOSAN toilets with high $\mathrm{pH}$ of more than 10 for faecal sludge and more than 11.5 for urine. Advocacy on the use of ECOSAN toilets improves the separated urine quality.

\section{REFERENCES}

[1] Addo N (2016). To Assess the Level of Heavy Metal Pollution in Groundwater in Ilala Dar es salaam. 
Msc. Thesis, Open University of Tanzania. OUT, http://repository.out.ac.tz/1537/

[2] APHA, AWWA and WEF (2002). Standard Methods for the Examination of Water and Wastewater, $20^{\text {th }}$ ed., Washington, DC

[3] Bethune DN; Chu A; Ryan MC (2015). Passive evaporation of source-separated urine from dry toilets: prototype design and field testing using municipal water, Journal of Water, Sanitation and Hygiene for Development. 5(3): 392-401.

[4] Breslin E (2014). Introducing ecological sanitation in northern Mozambique. WaterAid Mozambique.

[5] EEPCO (2007). Dry Ecological Sanitation Alternative in Tanzania. http://www.eepcotz.org/wp-content/uploads/2011/05/Dry-EcologicalSanitation-Alternative-in-Tanzania-2007.pdf

[6] Elisante E; Muzuka ANN (2002). Ecological Sanitation Toilets in Tanzania, $3^{\text {rd }}$ International Conference on Integrated Environmental Management in Southern Africa, Johannesburg, August 27-30.

[7] Elisante E; Muzuka ANN (2017). Occurrence of nitrate in Tanzanian groundwater aquifers: A review. Applied Water Science-Springer. P. 71-87.

[8] ENVIS Centre on Hygiene, Sanitation, Sewage Treatment Systems and Technology (2014). Lowcost Sanitation. http://www.sulabhenvis.nic.in/Database/LowCostSa nitation_5930.aspx.

[9] Esrey, AS; Hillers, A; Sawyer, R (2001). Closing the Loop: Ecological Sanitation for food Security. UNDP and SIDA, Publications on Water Resources, Mexico

[10] Farzadkia M; Bazrafshan E (2014). Lime Stabilization of Waste Activated Sludge. Health Scope International Journal, 3:1-5.

[11] Hijikata N; Yacouba H; Bonzi M; Coulibaly L (2015). Ecological sanitation products reuse for agriculture in Sahel: effects on soil properties. Soil Discuss. 2: 291-322.

[12] Hu M; Fan B; Wang H; Qu B; Zhu S (2016). Constructing the ecological sanitation: a review on technology and methods. Journal of Cleaner Production. p.1 - 21.

[13] Kujawa-Roeleveld K; Zeeman G (2016). Anaerobic Treatment in Decentralised and Source-Separation. Reviews in Environmental Science and Bio/Technology-Springer. 5 (1):115-139

[14] Mahenge AS (2013). The Study of Ecological Sanitation Systems in Dar es Salaam, Tanzania. International Journal of Development and Sustainability. 2:2256-2265.

[15] Mashauri, DA; Senzia, MA (2002). Reuse of Nutrients from Ecological Sanitation Toilets as a
Source of Fertiliser. $3^{\text {rd }}$ International Conference on Integrated Environmental Management in Southern Africa, Johannesburg, August 27-30. http://www.cemsa.com

[16] Nakagiri A; Niwagaba CB (2016). Are pit latrines in urban areas of Sub-Saharan Africa performing? A review of usage, filling, insects and odour nuisances. BMC. Public Health. 3(1): 1-16.

[17] Nansubuga I; Banadda N; Verstraete W (2016). A review of sustainable sanitation systems in Africa. Bio/Technology - Springer, 15:465 - 478

[18] Obeng PA; Oduro-Kwarteng S; Keraita B (2015). Impact of water pollution on human health and environmental: On-Site Sanitation Systems for LowIncome Countries. ed. McKeown, USA, p. 319-341.

[19] Semiyaga S; Okure M; Niwagaba C (2015). Decentralized options for faecal sludge management in urban slum areas of Sub-Saharan Africa: A review of technologies, practices and end-uses. Resources, Conservation and Recycling-Elsevier. 104:109-119.

[20] Shen KY (2013). Environmental Protection and Sustainable Development of Golf. Trans Tech Publ. p. 4069-4072.

[21] Strande L; Brdjanovic D (2014). Faecal sludge management: Systems approach for implementation and operation. IW A publishing, UK.

[22] Taseli BK; Kilkis B (2016). Ecological sanitation, organic animal farm, and cogeneration: Closing the loop in achieving sustainable development-A concept study with on-site biogas fueled trigeneration retrofit in a 900-bed university hospital. Science Direct. p. 129:102 - 119.

[23] Vliet B; Buuren J; Mgana S (2013). Urban Waste and Sanitation Services for Sustainable Development: Harnessing. Tanzania p. 1-153. 